\title{
Embryonal Neoplasm
}

National Cancer Institute

\section{Source}

National Cancer Institute. Embryonal Neoplasm. NCI Thesaurus. Code C3264.

A usually malignant neoplasm composed of primitive (immature) tissues that resemble fetal tissues. Medulloblastoma, ependymoblastoma, pineoblastoma, and Wilms tumor are representative embryonal neoplasms. 